\title{
Proximal-type epithelioid sarcoma - Case report ${ }^{\star}$
}

\section{Sarcoma epitelióide tipo proximal - Relato de caso}

\author{
Luciana Mendes dos Santos ${ }^{1}$ \\ Christiane Yuri Matsuo ${ }^{3}$ \\ Mônica Santos ${ }^{4}$
}

\author{
Lisiane Nogueira ${ }^{2}$ \\ Carolina Talhari ${ }^{4}$
}

\begin{abstract}
Epithelioid sarcoma, first described by Enzinger in 1970, is a rare soft-tissue sarcoma typically presenting as a subcutaneous or deep dermal mass in distal portions of the extremities of adolescents and young adults. In 1997, Guillou et al. described a different type of epithelioid sarcoma, called proximal-type epithelioid sarcoma, which is found mostly in the pelvic and perineal regions and genital tracts of young to middle-aged adults. It is characterized by a proliferation of epithelioid-like cells with rhabdoid features and the absence of a granuloma-like pattern. In this paper we present a case of proximal-type epithelioid sarcoma with an aggressive clinical course, including distant metastasis and death nine months after diagnosis.
\end{abstract}

Keywords: Diagnosis; Diagnosis, differential; Sarcoma; Therapeutics

Resumo: O sarcoma epitelióide, primeiramente descrito por Enzinger, em 1970, é uma neoplasia de partes moles que ocorre principalmente nas extremidades distais de adolescentes e adultos jovens. Em 1997, Guillou e cols. descreveram um tipo diferente de sarcoma epitelióide, que afetava frequentemente a região pélvica, períneo e áreas genitais de pacientes de média idade, com exame histológico caracterizado pela proliferação de células com aspecto epitelióide. Neste trabalho, descreve-se caso de paciente que apresentava há três meses duas lesões na região glútea, cujo exame histológico confirmou diagnóstico de sarcoma epitelioide do tipo proximal, já com presença de metástases pulmonares e cerebrais e que foi a óbito nove meses após o diagnóstico.

Palavras-chave: Diagnóstico; Diagnóstico diferencial; Sarcoma; Terapêutica

\section{INTRODUCTION}

Epithelioid sarcoma, first described by Enzinger in 1970, is a rare soft-tissue sarcoma typically presenting as a subcutaneous or deep dermal mass in distal portions of the extremities of adolescents and young adults. It is a slowly growing neoplasm with a strong propensity for local recurrence and, ultimately, metastasis. ${ }^{1}$ Microscopically, most tumors are characterized by a granuloma-like pattern: nodules of spindled and epithelioid cells circumscribe areas of central hyalinization and necrosis. Fibrous histiocytoma-like and angiomatoid subtypes have also been reported as less common histologic variants. ${ }^{2}$ In 1997, Guillou et al. described a different type of epithelioid sarcoma, called proximal-type epithelioid sarcoma, which is found mostly in the pelvic and perineal regions and genital tracts of young to middle-aged adults and is characterized by a proliferation of epithelioid-like cells with rhabdoid features and the absence of a granuloma-like pattern. ${ }^{3}$

Received on 10.06.2012.

Approved by the Advisory Board and accepted for publication on 10.07.2012.

* Study carried out at the Tropical Medicine Foundation of the Amazon State (Fundação de Medicina Tropical Dr. Heitor Vieira Dourado - FMT-HVD) - Manaus (AM), Brazil.

Conflict of interest: None

Financial funding: None

Dermatologist at the Tropical Medicine Foundation of the Amazon State (Fundação de Medicina Tropical Dr. Heitor Vieira Dourado - FMT-HVD) - Manaus (AM), Brazil.

Dermatologist. Professor of dermatology at the Federal University of Amazonas (UFAM) - Manaus (AM), Brazil

Dermatologist at the Tropical Medicine Foundation of the Amazon State (Fundação de Medicina Tropical Dr. Heitor Vieira Dourado - FMT-HVD) - Manaus (AM), Brazil.

4 Professor of dermatology at the State University of Amazonas (UEA) - Manaus (AM), Brazil.

(C)2013 by Anais Brasileiros de Dermatologia 


\section{CASE REPORT}

In 2009, a 25-year-old man was referred to the dermatology department with a 3-month history of a rapidly growing painful mass on his right buttock which subsequently ulcerated. Skin examination revealed an erythematous infiltrated plaque and an ulcerated lesion with fibrinous exudate in the gluteal region (Figure 1). There were no lymphadenopathies or other abnormalities on physical examination. A skin biopsy of the ulcerated lesion revealed proliferation of pleomorphic epithelioid cells with eosinophilic cytoplasm and vesicular nuclei with prominent nucleoli. Scattered rhabdoid cells characterized by abundant glassy cytoplasm, eccentric nuclei and prominent nucleoli were observed throughout the lesion (Figure 2). Immunohistochemistry showed positivity for vimentin, cytokeratin, EMA, CAM 5.2, MIB and CD34 for the latter marker positivity was focal confirming the diagnosis of proximal-type epithelioid sarcoma (Figure 3). Blood count and serum biochemistry were unremarkable, and culture for mycobacteria, fungi
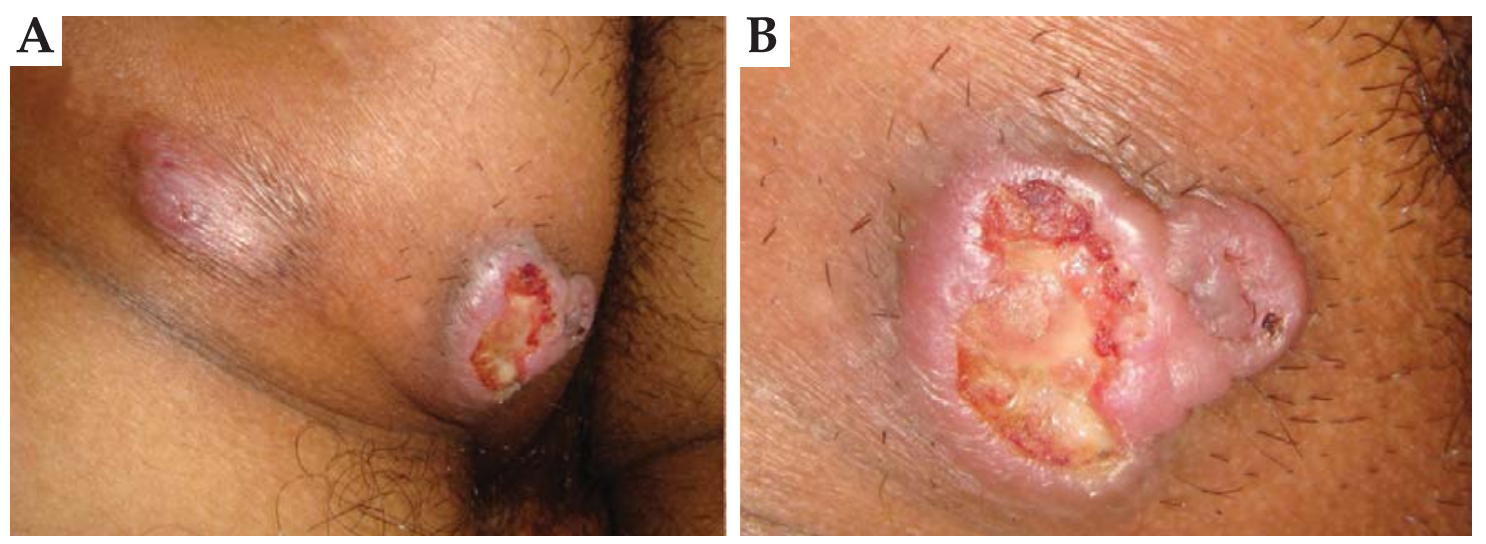

Figure 1: Two lesions located on the gluteus: the first, which is $6 \mathrm{~cm}$ in diameter, is ulcerated and has elevated, infiltrated edges; the second, a plaque, is reddishpurple with a fibrous consistency and $4 \mathrm{~cm}$ in diameter
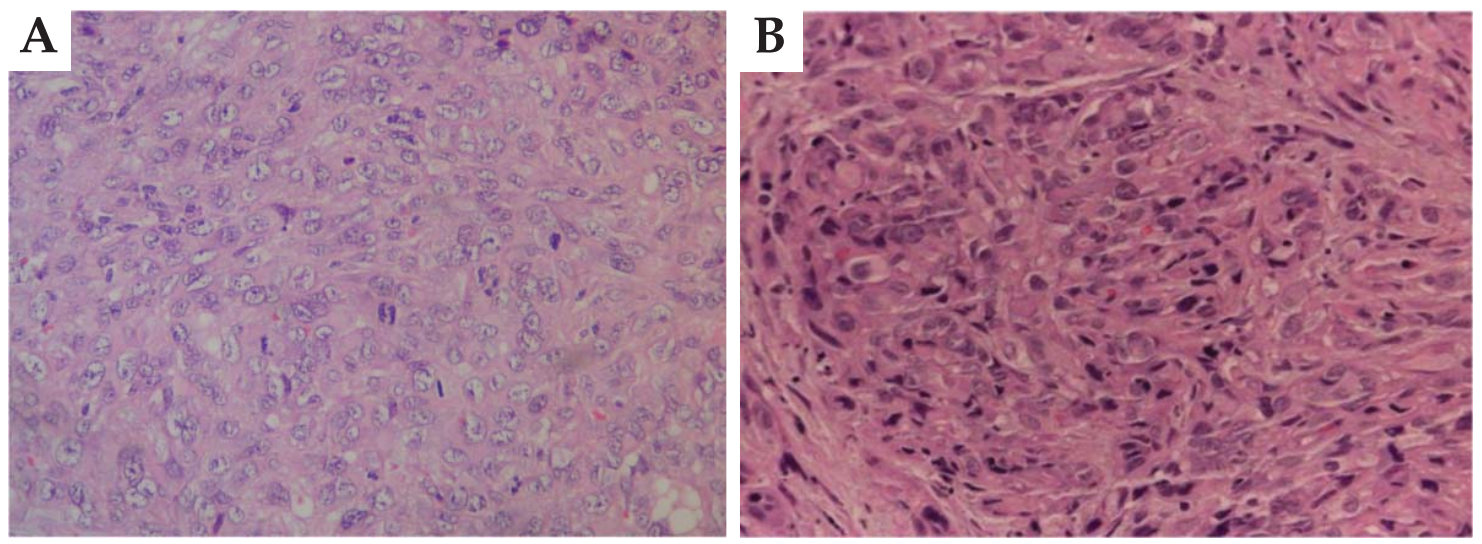

FIGURE 2:

Epithelioid cells with moderate pleomorphism eosinophilic cytoplasm and prominent vesicular nuclei and scattered rhabdoid cells with hyaline intracytoplasmic inclusions displacing the nucleus eccentrically
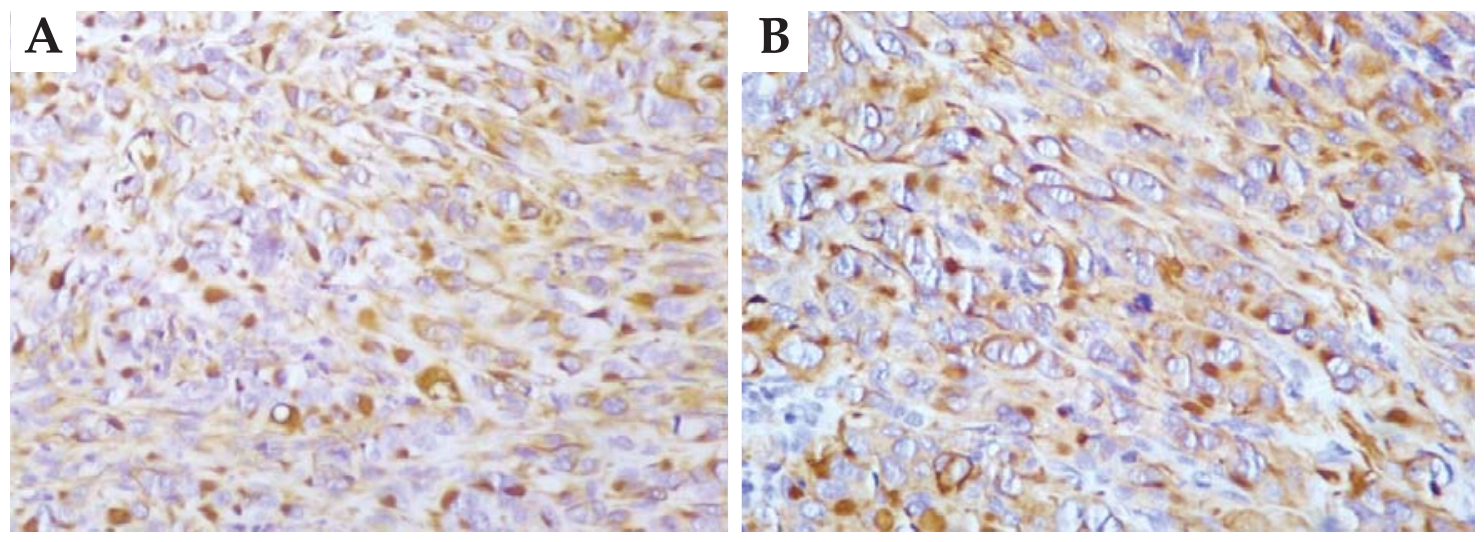

FIGURE 3

Epithelioid and rhabdoid cells exhibiting positivity for vimentin and cytokeratin 
and aerobic bacteria were negative. At the time of diagnosis, the tests to define clinical staging, which included a computed tomography scan, revealed numerous metastatic lesions in the brain and lungs (Figure 4). The patient received chemotherapy at a reference oncology institute but died in the ninth month of follow-up.

\section{DISCUSSION}

The clinical, morphological and immunohistochemical features of the case described here are in accordance with those of proximal-type epithelioid sarcoma. Clinically, the proximal-type variant differs from the classic form of epithelioid sarcoma in that it frequently occurs in older patients in a proximal/ axial often deep-seated location, preferentially involving the pelvic, perineal and genital regions, it is apparently more aggressive and metastasizes earlier than the conventional distal-type epithelioid sarcoma ${ }^{4}$ Histologically, it tends to be characterized by predominantly epithelioid cells, marked cytologic atypia, the frequent occurrence of rhabdoid features and the absence of a granuloma-like pattern..$^{5}$ All variants of epithelioid sarcoma co-express vimentin and cytokeratin. The histogenetic origin of epithelioid sarcoma is unknown, but a hypothesis that it originates from
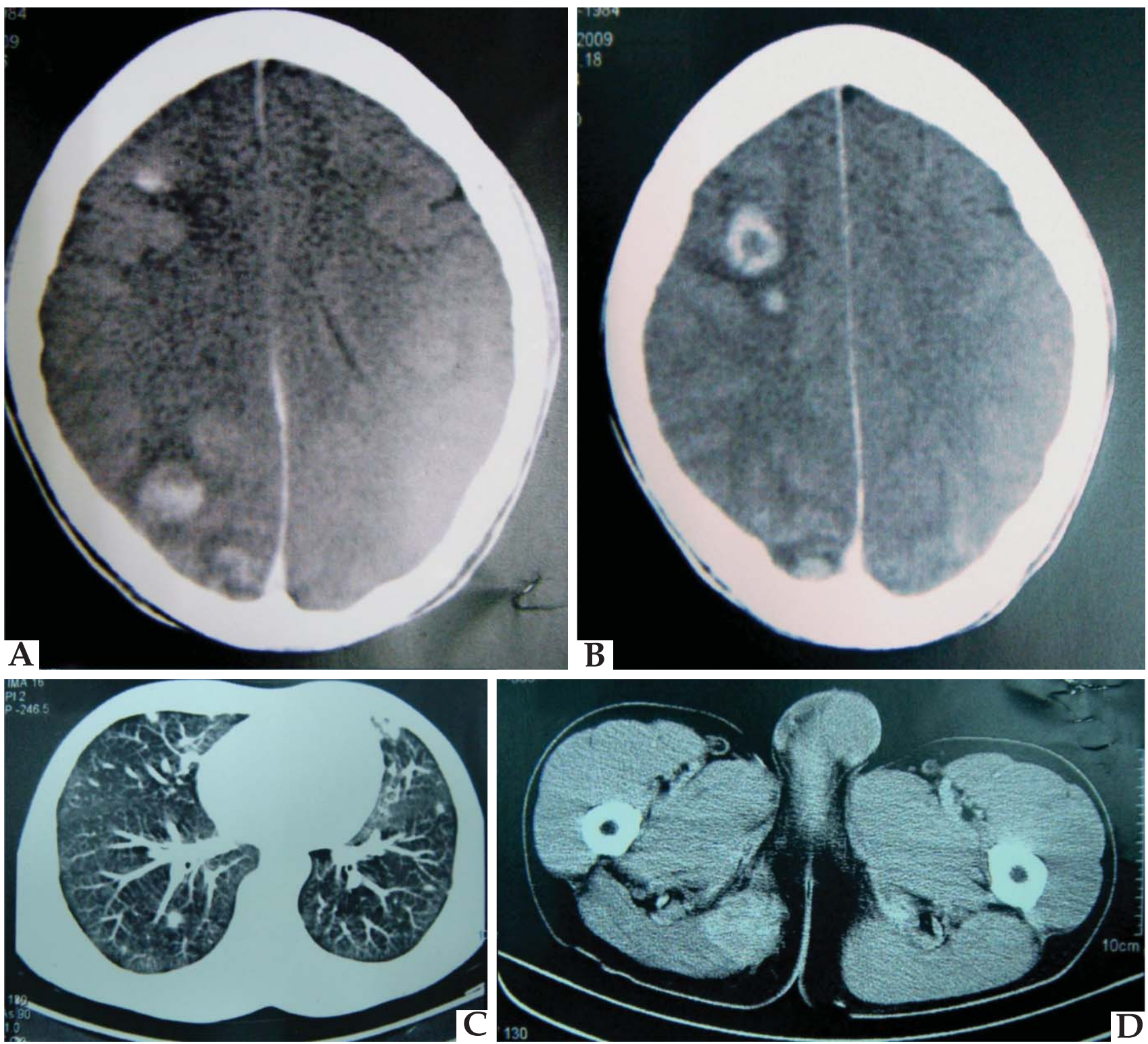

FIGURE 4: Tomography scans showing lung and brain metastases 
mesenchymal cells undergoing epithelial differentiation has been favored. ${ }^{6,7}$ Differential diagnosis of proximal-type epithelioid sarcoma includes epithelioid malignant peripheral nerve-sheath tumor, clear cell sarcoma, epithelioid hemangioendothelioma, angiosarcoma, epithelioid leiomyosarcoma, synovial sarcoma, rhabdomyosarcoma and metastatic carcino- ma. In an endemic area for leishmaniasis, it should also be differentiated from an ulcerated lesion with infiltrated edges caused by leishmaniasis. ${ }^{8}$ In this paper we present a case of proximal-type epithelioid sarcoma with an aggressive clinical course, including distant metastasis and death nine months after diagnosis.

\section{REFERENCES}

1. Enzinger FM. Epithelioid sarcoma: a sarcoma simulating a granuloma or a carcinoma. Cancer. 1970,26:1029-41.

2. Fleury Jr LFF, Sanches Jr JA. Primary cutaneous sarcomas. An Bras Dermatol. 2006;81:207-21.

3. Guillou L, Wadden C, Coindre JM, Krausz T, Fletcher CM. "Proximal- Type" epithelioid sarcoma, a distinctive aggressive neoplasm showing rhabdoid features. Am J Surg Pathol. 1997;21:130-46.

4. Lee MW, Jee KJ, Ro JY, Lee DP, Choi JH, Moon KC, et al. Proximal type epithelioid sarcoma: case report and result of comparative genomic hybridization. J Cutan Pathol. 2004;31:67-71.

5. Gambini C, Sementa A, Rongioletti F. "Proximal-type" epithelioid sarcoma in a young girl. Pediatr Dermatol. 2004;21:117-20.

6. Tardio JC. CD34-reactive tumors of the skin. An updated review of an ever-growing list of lesions. J Cutan Pathol. 2008;35:1079-92.

7. Lin L, Skacel M, Sigel JE, Bergfeld WF, Montgomery E, Fisher C, et al. Epithelioid sarcoma: an immunohistochemical analysis evaluating the utility of cytokeratin $5 / 6$ in distinguishing superficial epithelioid sarcoma from spindled squamous cell carcinoma. J Cutan Pathol. 2003;30:114-7.

8. Hasegawa T, Matsuno Y, Shimoda T, Umeda T, Yokoyama R, Hirohashi S. Proximaltype epithelioid sarcoma: a clinicopathologic study of 20 cases. Mod Pathol. 2001;14:655-63.

\author{
MAILING ADDRESS: \\ Av. Djalma Batista, 1061, Shopping Millennium, \\ Torre Medica, salas 609 e 610 - Chapada \\ 69050-010 - Manaus - AM \\ Brazil \\ E-mail:m.n.souza.santos@gmail.com
}

How to cite this article: Mendes dos Santos L, Nogueira L, Matsuo CY, Talhari C, Santos M. Proximal-type epithelioid sarcoma - Case report. An Bras Dermatol. 2013;88(3):444-7. 